\section{A New Local Sustainable Inorganic Material for Soilless Culture in Spain: Granulated Volcanic Rock}

\author{
Judith Pozo \\ Departamento de Agronomía, Universidad de Almería, Almería, Spain
}

Juan E. Álvaro

Escuela de Agronomía, Pontificia Universidad Católica de Valparaíso, Chile

Isidro Morales, Josefa Requena, and Tommaso La Malfa

Departamento de Agronomía, Universidad de Almería, Almería, Spain

Pilar C. Mazuela

Facultad de Agronomía, Universidad de Tarapacá, Arica, Chile

\author{
Miguel Urrestarazu ${ }^{1}$ \\ Departamento de Agronomía, Universidad de Almería, Almeria, Spain
}

Additional index words. sustainable substrate, alternative substrate, horticultural substrate, environmental care, coconut fiber

\begin{abstract}
Volcanic rock has been used for decades as a horticultural substrate worldwide. In Spain, the use of this material as a substrate is ancient; it was initially used in the Canary Islands because of its volcanic geological origin. At the University of Almería (Almería, Spain), three independent vegetable crops were grown under greenhouse conditions: sweet pepper, tomato, and melon. The volcanic rock came from a location in the geographic center of Spain, which facilitated logistics. Bags of volcanic rock (25 L) were used and were compared with a commercial coconut fiber substrate of an equal volume. All physical, physical-chemical, and chemical parameters of the volcanic rock were determined using European standard analytical procedures. Fertigation was applied, independently adapted to the physical, physical-chemical, and chemical characteristics of each substrate. The cultures were performed under a randomized complete block experimental design. Fertigation parameters, pollutant emissions, fruit production, and the quality of each culture were measured. The results showed that the assessed parameters of the volcanic rock substrate are not a limiting factor for its use as a horticultural substrate. The resultant production and quality were very similar among the three crops compared with a widely used commercial control. Therefore, volcanic rock emerges as a local, sustainable alternative to be used for soilless crop cultivation.
\end{abstract}

Soilless cultivation in volcanic rock began with some profusion in the 1940s (Gericke, 1940). In regions where this material is common, it is widely used such as in Central America including in Costa Rica, Guatemala, and especially in southern Mexico. Specifically, in Mexico, this substrate is currently being developed with great prodigality under the name of tezontle (Ponce Lira et al., 2013; Rodríguez Diaz et al., 2013; San MartínHernández et al., 2012; Urrestarazu, 2013). Cultivation in this material is also very common in Hawaii, where such systems are among the most commercially widespread in soilless crops (McCall and Nakagawa, 1979) as well as in certain areas of Europe (Gizas and Savvas, 2007).

Received for publication 26 Sept. 2014. Accepted for publication 12 Oct. 2014.

We thank the LAFARGE@ Company for supporting this work.

${ }^{1}$ To whom reprint requests should be addressed; e-mailmgavilan@ual.es.

The cultivation of crops in volcanic rock is also not a recent phenomenon in Spain. References to the beginnings of this practice can be found from the early 1970s at the International Center for Hydroponics in Las Palmas in the Canary Islands (Blesa and Luque, 1972). Cultivation was conducted in 1 -m-wide beds with subirrigation using volcanic lapilli as a substrate, which is locally referred to as "picón." This practice was first performed in glass greenhouses at the island of Lanzarote (Canary Islands, Spain) using various crops such as cucumber, melon. and tomato (Arán, 1977, 1978a, 1978) and is still used today (Baixauli and Aguilar, 2002; Santos and Ríos, 2013). Crops have been developed in both containers and flower beds, in large elongated containers, $\approx 0.5$ or $1 \mathrm{~m}$ wide and several meters long, and in individual containers in which one or a small number of plants are grown. In the Canary Islands, the growing area in volcanic rock is estimated to be $\approx 225$ ha (Baixauli and Aguilar, 2002). This natural and granular volcanic material (pozzolan) has been widely described in various parts of the world (Table 1). In the remainder of Spain, outside of the Canary Islands, this material is not widely used compared with other soilless systems that are more widely dispersed such as rockwool, perlite, or coconut fiber, which occupy areas of $\approx 5000$ to 5500 ha (Urrestarazu, 2013).

Currently, the commercial potential of such volcanic materials is being evaluated by the international company Lafarge ${ }^{\odot}$ in central Spain. The formation of these volcanic materials was described by González et al. (2008) as originating in Laharic facies in base surge deposits in Barranco Varondillo, Campo de Calatrava (Spain). The Barranco Varondillo maar was generated through phreatomagmatic eruptions and has favored the formation of deposits of wet surges. The deposition of these materials, subject to the use proposed here, has been estimated at 5,360,419 t. Once sieved, a standardized material is obtained as described in the "Materials and Methods."

Many materials that can potentially be used as horticultural substrates have been described in Spain (Abad et al., 2001; MAAM, 2014), also considering the benefits of their being local and sustainable (Urrestarazu et al., 2005) to mitigate the carbon footprint resulting from long-range substrate transport. Such a situation exists for coconut fiber, which is produced mainly in India or Sri Lanka and supplies central and southern Europe. Similar issues, but with a different root cause, arise for new genesis products such as rockwool or perlite, which require a large input of energy because high temperatures must be achieved for their manufacture.

This work aims to physically, physicalchemically, and chemically characterize a local sustainable volcanic rock substrate and to agronomically evaluate its use in three vegetable crops compared with the commercially widely used substrate of coconut fiber.

\section{Materials and Methods}

Cultivation conditions. Three independent crops were grown at the facilities of the University of Almeria (Spain) in a plastic greenhouse $(200 \mu \mathrm{m}$ thick). The cultivation management scheme followed methods that re commonly used in the cultivation area. Table 2 shows the main parameters of all three crops.

Treatments. The assessed treatment was a bag $(100 \times 25 \times 10 \mathrm{~cm})$ of volcanic rock (VR) of $25 \mathrm{~L}$, supplied by the Lafarge Company, Spain. The evaluated horticultural substrate was a naturally occurring granular, irregular type of volcanic rock. The texture and particle distribution characteristics of the substrate are shown in Table 3. This material is obtained through direct extraction from a quarry and subsequent controlled grinding and sieving. The texture remains homogeneous in each culture unit. The volcanic rock bags were developed manually with a $115-\mu \mathrm{m}$-thick bicolor coextruded plastic sheet, similar to that surrounding the commercial control unit. 
Table 1. Variation in some characteristics of pozzolans (volcanic rocks) used in soilless culture systems worldwide.

\begin{tabular}{|c|c|c|c|c|c|c|c|c|c|}
\hline \multirow{2}{*}{\multicolumn{2}{|c|}{ Density $\left(\mathrm{kg} \cdot \mathrm{L}^{-1}\right)$}} & \multirow{2}{*}{\multicolumn{2}{|c|}{ Porosity ( $\%$ in volume) }} & \multicolumn{3}{|c|}{ Percent volume } & \multirow[b]{3}{*}{ Inert/stability } & \multirow{3}{*}{$\begin{array}{l}\text { Cation exchange } \\
\text { capacity } \\
(\mathrm{mEq} / 100 \mathrm{~g})\end{array}$} & \multirow{3}{*}{$\begin{array}{c}\text { References and } \\
\text { observations }\end{array}$} \\
\hline & & & & \multirow{2}{*}{$\begin{array}{c}\text { Air } \\
\text { capacity }\end{array}$} & \multirow{2}{*}{$\begin{array}{l}\text { Easily available } \\
\text { water }\end{array}$} & \multirow{2}{*}{$\begin{array}{c}\text { Buffer } \\
\text { capacity }\end{array}$} & & & \\
\hline Apparent & Real & Total & Occluded & & & & & & \\
\hline $0.7-0.8$ & & $50-60$ & $8-13$ & $30-40$ & $4-5$ & $<2$ & Yes/high & 5 & Baixauli and Aguilar $(2002)^{z}$ \\
\hline 0.77 & 2.65 & 70.94 & & 48.45 & 6.65 & 1.63 & Yes/very high & & Burés (1997); red volcanic ${ }^{z}$ \\
\hline 0.90 & 2.93 & 68.60 & & 53.90 & & & Yes/very high & & Jeangille (1991); mean data \\
\hline 0.92 & & 55.5 & & 40.67 & & & Yes/very high & 2.5 & Rodríguez et al. (2013) ${ }^{\mathrm{y}}$ \\
\hline
\end{tabular}

${ }^{2}$ From the Canary Islands (Picón).

${ }^{\mathrm{y}}$ From Mexico (Tezontle).

Table 2. Main parameters of culture cycles done during the assays.

\begin{tabular}{llcccc}
\hline Crop & Cultivars & $\begin{array}{c}\text { Plantation density } \\
\left.\text { (plants } / \mathrm{m}^{2}\right)\end{array}$ & $\begin{array}{c}\text { Transplant } \\
\text { date }\end{array}$ & $\begin{array}{c}\text { Harvesting } \\
\text { date }\end{array}$ & $\begin{array}{c}\text { Final harvesting } \\
\text { date }\end{array}$ \\
\hline $\begin{array}{l}\text { Sweet pepper } \\
\text { Tomato }\end{array}$ & $\begin{array}{l}\text { Padua RZ f1 } \\
\text { Zinac grafted } \\
\text { on Beaufort }\end{array}$ & 2 & 14 Oct. 2013 & 10 Jan. 2014 & 16 May 2014 \\
Melon & Brisa & 1 & 18 Feb. 2014 & 25 Apr. 2014 & 26 May 2014 \\
\hline
\end{tabular}

Table 3. Texture and particle size distribution $(\%$ weigh) of volcanic rock substrate.

\begin{tabular}{lcccccc}
\hline \multicolumn{7}{c}{$\mathrm{mm}$} \\
\hline$<1$ & $1-2$ & $2-4$ & $4-8$ & $8-16$ & $16-32$ & $>32$ \\
24.4 & 18.6 & 25.3 & 26.8 & 4.72 & - & - \\
\hline
\end{tabular}

Determination as per AENOR (2008a)

The control treatment $(\mathrm{CF})$ was a similar commercial unit consisting of a Pelemix GB1002410 ${ }^{\circledR}$ coir grow bag $(100 \times 25 \times$ $10 \mathrm{~cm}$ ) with a cultivation volume of $25 \mathrm{~L}$.

Fertigation conditions. For each treatment, two controls were established as fertigation controls, consisting of a control dripper and a drain pan that served as points for the measurement and monitoring of the supplied fertigation and the absorption response. At these locations, the volume of the nutrient solution as well as the $\mathrm{pH}$ and electrical conductivity (EC) of the fertigation input and the drainage were measured on a daily basis. These feedback data supplied the fertigation scheduling program. The contents of nitrate and potassium were also measured with automatic systems from HORIBA $^{\odot}$ Ltd. Japan (LAQUAtwin B-741 and LAQUAtwin B-731, respectively). The macro- and micronutrient composition of the nutrient solution was as proposed by Sonneveld and Straver (1994). Fertigation was conducted using three self-compensating, antidraining drips per culture unit with four diffusers, as reported by Morales and Urrestarazu (2013) and Wamser et al. (2014).

The nitrate and potassium contents in the drainage were measured on a weekly basis in the tomato and sweet pepper crops using ion chromatography (Urrestarazu et al., 2008a). The absorption of nitrates and potassium in $\mathrm{mmol} \cdot \mathrm{m}^{-2}$ and their emissions in $\mathrm{g} \cdot \mathrm{m}^{-2}$ were quantified based on the concentration and volume of drained fertigation.

For each independent treatment, irrigation was performed when $10 \%$ of the easily available water in the substrate had been exhausted applying the necessary volume to produce between $15 \%$ to $25 \%$ drainage (Urrestarazu, 2004; Urrestarazu et al., 2005, 2008b). Additionally, the nutrient solution was applied, and the drainage was monias described by Rodríguez et al. (2015). The duration of each irrigation event was selected by adjusting the volume to be supplied to each cultivation unit depending on the obtained soil water release curve (Fig. 1). To generate the water release curve, the concept described De Boodt et al. (1974) was applied. The following volumes were calculated (vol:vol): effective total porosity (volumetric percentage of pore space), air volume after drainage (air content at $10-\mathrm{cm}$ water suction, air capacity), readily available water (difference in the volumetric water content between 10 - and $50-\mathrm{cm}$ water suction), and the buffering capacity (difference in the volumetric water content between 50and $100-\mathrm{cm}$ water suction) and hardly available water. Measurements were performed following European substrate regulations (AENOR, 2012a).

Other physical, physical-chemical, and chemical characteristics were determined under European substrate regulations (AENOR 2002a, 2002b, 2008a, 2008b, $2012 \mathrm{a}, 2012 \mathrm{~b}, 2012 \mathrm{c}$ ), which are shown in Table 4.

Harvest sampling. Harvesting of individual fruits was conducted for each crop on a weekly basis. Tomatoes were harvested once they had reached a state of maturity corresponding to a uniform red color of the tomato skin. The tomatoes were sized according to their equatorial diameter and the prevailing commercial fruit category (DOUE, 2000); sweet pepper and melon were not calibrated. In all crops, the non-marketable product was less than 5\%. From each harvest, a subsample of three tomato and sweet pepper fruits was used to produce a homogenized solution to quantify the $\mathrm{pH}, \mathrm{EC}$, and total soluble solids (expressed as ${ }^{\circ}$ Brix), which were measured with a digital refractometer (Atago PAL-1). After drying the fruit in a forced-air oven at $85^{\circ} \mathrm{C}$ for $72 \mathrm{~h}$, the dry matter content was obtained by weighing three tomatoes with an accuracy of one-hundredth of a gram. $\mathrm{pH}$ and EC were not considered in the case of fruits. tored through a computerized control system
All measurements characterizing the substrates were performed in quadruplicate. Operations that are commonly used in culture were applied regarding the treatment of the culture units, the distribution of these units, and the other culture management procedures for each crop.

Experimental design and statistical analysis. The experiments were conducted using a split-plot design (Little and Hill, 1978; Petersen, 1994) with three blocks per treatment. The experimental unit comprised three culture units.

\section{Results and Discussion}

Figure 1 shows how the characteristics of the water release curve adjust substantially to the gravel materials used in the Canary Islands in Spain (Baixauli and Aguilar, 2002) as well as for materials used in other countries such as for tezontle in Mexico (Ponce Lira et al., 2013) or pumice in Greece (Gizas and Savvas, 2007). The air capacity (31.81\%) of the volcanic rock was similar to that of coconut fiber $(32.0 \%)$. However, all of the water parameters measured in the substrate showed substantially lower values in the volcanic rock vs. the coconut fiber $(10 \%$, $0.2 \%$, and $12.2 \%$ for easily available water, the buffering capacity of water, and hardly available water, respectively).

Table 4 shows the physical, physicalchemical, and chemical characteristics of the volcanic rock. None of the measured parameters was a limiting factor for the growth of the vegetables. The laboratory-compacted apparent density of the volcanic substrate $\left(1.37 \mathrm{~kg} \cdot \mathrm{L}^{-1}\right)$ exceeded that of the coconut fiber $\left(0.06 \mathrm{~kg} \cdot \mathrm{L}^{-1}\right)$ (Urrestarazu, 2004). This high value is a significant drawback compared with other substrates such as rockwool or perlite, which are up to 10 times lighter, implying consequent ease of operation.

Effects on fertigation parameters. Table 5 shows the performance of the fertigation parameters used to control the correct application of the nutrient solution. Significant differences were found between the two tested substrates in all of the measured fertigation parameters of the drainage samples, except for EC in the tomato crop. The percentage of volcanic rock drainage was maintained at lower and higher levels during the cultivation of sweet pepper and tomato, respectively.

The $\mathrm{pH}$ was significantly higher in the VR than the CF in both cultures. The drainage EC for the CF substrate was significantly higher 

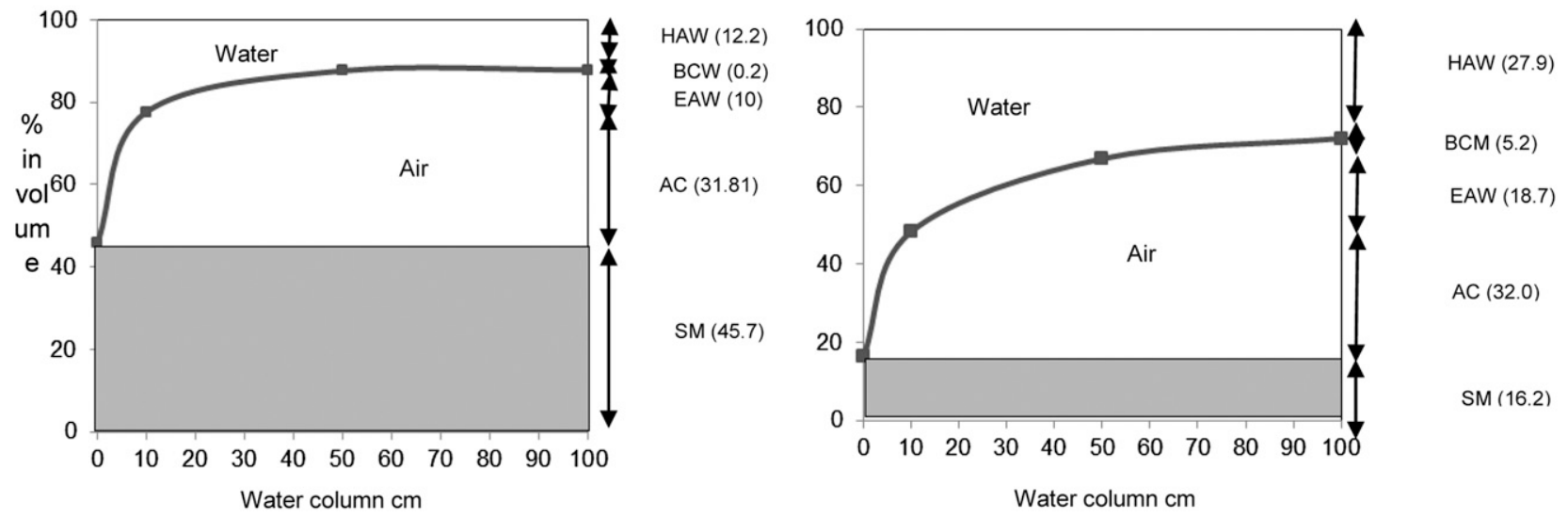

Fig. 1. Water release curve of two substrates (based on De Boodt et al., 1974). HAW = hardly available water; BCW = buffering capacity water; EAW = easy available water; $\mathrm{AC}=$ air capacity; $\mathrm{SM}=$ solid matter.

Table 4. Physical, physical-chemical, and chemical characteristics of volcanic rock substrate.

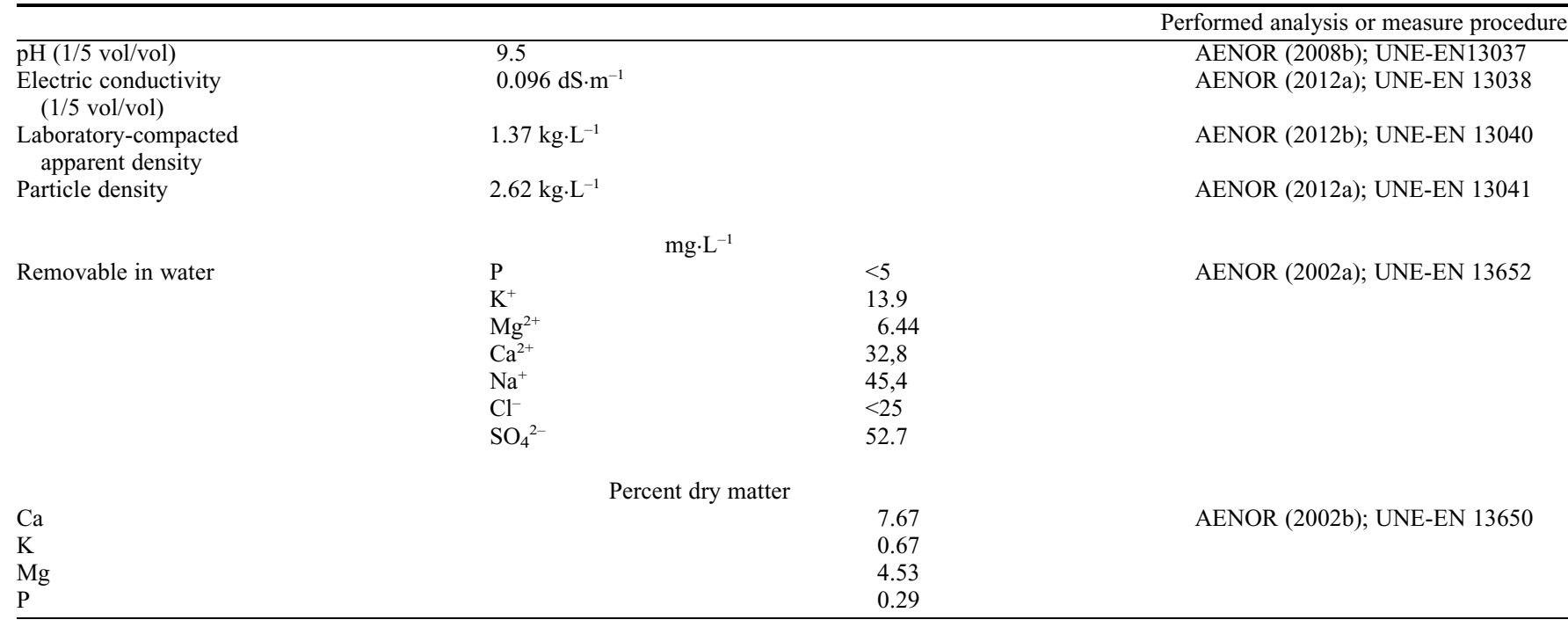

Table 5. Fertigation parameters, water, nitrate, and potassium absorption and emissions.

\begin{tabular}{|c|c|c|c|c|c|c|c|c|c|c|c|c|c|c|}
\hline \multirow[b]{3}{*}{ Crop } & & & & & & & \multicolumn{6}{|c|}{ Uptake } & \multirow{2}{*}{\multicolumn{2}{|c|}{$\begin{array}{c}\text { Emission } \\
\left(\mathrm{g} \cdot \mathrm{m}^{-2}\right) \\
\end{array}$}} \\
\hline & \multicolumn{6}{|c|}{ Drainage } & & & \multicolumn{4}{|c|}{$\left(\mathrm{mmol} \cdot \mathrm{m}^{-2}\right)$} & & \\
\hline & VR & $\mathrm{CF}$ & $\overline{\mathrm{VR}}$ & $\mathrm{CF}$ & VR & $\mathrm{CF}$ & VR & $\mathrm{CF}$ & VR & $\mathrm{CF}$ & VR & $\mathrm{CF}$ & VR & $\mathrm{CF}$ \\
\hline Tomato & 14.07 & $14.61^{* *}$ & 8.24 & $7.46^{*}$ & 3.08 & $3.91 \mathrm{NS}$ & 128.09 & $126.90 \mathrm{NS}$ & 0.887 & $0.898 \mathrm{NS}$ & 0.537 & $0.521 \mathrm{NS}$ & 7.75 & $7.08^{*}$ \\
\hline
\end{tabular}

$*, * *$, Ns indicate significant differences at $P \leq 0.05, P \leq 0.01$ and nonsignificant differences, respectively.

$\mathrm{EC}=$ electrical conductivity; $\mathrm{VR}=$ volcanic rock; $\mathrm{CF}=$ control treatment.

(by $27 \%$ ). Water absorption in the VR substrate was significantly lower, by $20 \%$, in the sweet pepper crop, whereas the tomato crop was unaffected.

The measured quantities of absorbed nutrients were similar to those obtained from other alternative local substrates such as almond shell waste used for tomato cultivation (Urrestarazu et al., 2005, 2008c), a compost-based substrate (Urrestarazu et al., 2008c) and coconut fiber used for melon and cucumber crops (Urrestarazu et al., 2008b).
When the differential absorption between VR and CF was compared, the only significant difference was found for CF (by $30 \%$ ) in the sweet pepper culture, whereas this difference was not significant in the tomato crop.

Effect on pollutant emissions. The measured nitrate emission levels are similar to those reported for other horticultural crops (Urrestarazu et al., 2008a). However, a much smaller proportion was recorded for the tomato crop, probably because a percentage of drainage above $15 \%$ was not required, because the EC values remained below $4 \mathrm{dS} \cdot \mathrm{m}^{-1}$ in this case, and the period of cultivation was shorter. Nitrate emissions were higher in the VR substrate, by $23 \%$ and $8 \%$ for the sweet pepper and tomato crops, respectively.

Effect on production. Table 6 shows the production and number of fruits obtained from the sweet pepper, tomato, and melon crops. No significant difference in the three crops was recorded between the VR and $\mathrm{CF}$ substrates. Some investigations 
Table 6. Fruit production and number according to crop in the volcanic rock (VR) and coconut fiber (CF) substrate.

\begin{tabular}{lrrrrr}
\hline & \multicolumn{2}{c}{$\mathrm{kg} \cdot \mathrm{m}^{-2}$} & & \multicolumn{2}{c}{ Fruit $/ \mathrm{m}^{2}$} \\
\cline { 2 - 3 } \cline { 6 - 7 } Crop & VR & CF & & \multicolumn{1}{c}{ VR } & \multicolumn{1}{c}{ CF } \\
\hline Sweet pepper & 6.50 & $6.86 \mathrm{NS}$ & & 280.93 & $297.57 \mathrm{NS}$ \\
Tomato & 6.76 & $6.78 \mathrm{NS}$ & & 37.17 & $39.33 \mathrm{NS}$ \\
Melon & 3.60 & $3.86 \mathrm{NS}$ & & 1.88 & $2.25 \mathrm{NS}$ \\
\hline
\end{tabular}

Ns indicates nonsignificant differences at $P \leq 0.05$.

Table 7. Production $\left(\mathrm{kg} \cdot \mathrm{m}^{-2}\right)$ by fruit size according to the volcanic rock (VR) and coconut fiber substrate $(\mathrm{CF})$ in tomato crop.

\begin{tabular}{lcl}
\hline & VR & \multicolumn{1}{c}{ CF } \\
\hline GG $(81-102 \mathrm{~mm})^{2}$ & 3.43 & $2.91^{*}$ \\
G $(67-81 \mathrm{~mm})$ & 1.97 & $2.31^{*}$ \\
M $(57-67 \mathrm{~mm})$ & 0.83 & $1.01 \mathrm{NS}$ \\
MM $(47-57 \mathrm{~mm})$ & 0.46 & $0.50 \mathrm{NS}$ \\
MMM $(40-47 \mathrm{~mm})$ & 0.07 & $0.02^{*}$ \\
\hline
\end{tabular}

${ }^{\mathrm{z}}$ Source: DOUE (2000).

${ }^{*}$, Ns indicate significant differences at $P \leq 0.05$ and nonsignificant differences, respectively.

Table 8 . Fruit quality parameters according to the volcanic rock (VR) and coconut fiber substrate (CF) in sweet pepper and tomato crops.

\begin{tabular}{|c|c|c|c|c|c|c|c|c|}
\hline \multirow[b]{2}{*}{ Crop } & \multicolumn{2}{|c|}{$\mathrm{pH}$} & \multicolumn{2}{|c|}{$\mathrm{EC}\left(\mathrm{dS} \cdot \mathrm{m}^{-1}\right)$} & \multicolumn{2}{|c|}{${ }^{\circ}$ Brix } & \multicolumn{2}{|c|}{ DM (\%) } \\
\hline & $\overline{V R}$ & $\mathrm{CF}$ & $\overline{V R}$ & $\mathrm{CF}$ & $\overline{\mathrm{VR}}$ & $\mathrm{CF}$ & $\overline{\mathrm{VR}}$ & $\mathrm{CF}$ \\
\hline Sweet pepper & - & - & - & - & 3.14 & $2.91^{*}$ & 8.70 & $7.86^{* *}$ \\
\hline Tomato & 4.34 & $4.45 \mathrm{NS}$ & 4.36 & $4.55 \mathrm{NS}$ & 4.53 & $4.55 \mathrm{NS}$ & 9.65 & $9.11 \mathrm{NS}$ \\
\hline
\end{tabular}

*,**, Ns indicate significant differences at $P \leq 0.05, P \leq 0.01$ and nonsignificant differences, respectively. $\mathrm{DM}=$ dry matter.

examining other potential local substrates have not shown significant differences, for example, when almond shells were compared with rock wool waste in tomato and melon crops (Urrestarazu et al., 2005) or when a maguey bagasse substrate was compared with coconut fiber in cucumber and melon (Martínez et al., 2012) or the work by Gruda and Schnitzler (2004) using wood fiber as a substrate for growing tomato plants.

Effect on fruit quality. Comparing the two substrates, a higher proportion $(15 \%)$ was recorded in larger-sized tomatoes for the VR substrate (Table 7). This outcome represents a significant benefit to the farmer, because such fruits receive a higher price in marketing channels (Morales and Urrestarazu, 2013). However, for the next caliber in size, the larger proportion was found in the CF substrate. A significant difference in favor of VR was also recorded in the smaller caliber.

Effect on quality parameters. Table 8 shows the measured quality data. In the sweet pepper crop, higher proportions were recorded in the ${ }^{\circ}$ Brix and dry matter parameters in favor of the VR substrate, by $7 \%$ and $10 \%$, respectively. No significant differences were recorded for any of the measured parameters in the tomato crop. Similar results were obtained in the tomato crop when a different $\mathrm{EC}$ in the coconut fiber substrate was applied with an effect on the caliber distribution being recorded, whereas the overall production and quality parameters were unaffected (Morales and Urrestarazu, 2013).

\section{Conclusions}

The parameters measured to characterize the volcanic rock evaluated in this work did not indicate any limitation for its use as a horticultural substrate. When fertigation is adapted to the physical, physical-chemical, and chemical properties of VR, the resultant commercial production and quality are similar to those obtained using other commercially common substrates. Therefore, VR can be used as an alternative local, sustainable substrate because it does not require high-energy input for its manufacture nor does it generate mining subproducts or require long-distance transportation, producing a significant carbon footprint. Furthermore, it is a very stable substrate that can be used during long periods of cultivation.

\section{Literature Cited}

Abad, M., P. Noguera, and S. Burés. 2001. National inventory of organic wastes for use as growing media for ornamental potted plant production: Case study in Spain. Bioresour. Technol. 77: $197-200$.

AENOR. 2002a. UNE-EN 13652:2002. Mejoradores de suelo y sustratos de cultivo. Extracción de nutrientes y elementos solubles en agua. [Soil improvers and growing media-Extraction of water soluble nutrients and elements].

AENOR. 2002b. UNE-EN 13650 (modificado). Mejoradores de suelo y sustratos de cultivo. Extracción de elementos solubles en agua regia. [Soil improvers and growing media-Extraction of aqua regla soluble elements].

AENOR. 2008a. UNE-EN 15428:2008. Mejoradores de suelo y sustratos de cultivo. Determinación de la granulometría de las partículas. [Soil improvers and growing media-Determination of particle size distribution].

AENOR. 2008b. UNE-EN 13040:2008. Mejoradores de suelo y sustratos de cultivo. Preparación de la muestra para ensayos físicos y químicos. Determinación del contenido de materia seca, del contenido de humedad y de la densidad aparente compactada en laboratorio. [Soil improvers and growing mediaSample preparation for chemical and physical tests, determination of dry matter content, moisture content and laboratory compacted bulk density].

AENOR. 2012a. UNE-EN 13041:2012. Mejoradores de suelo y sustratos de cultivo. Determinación de las propiedades físicas. Densidad aparente seca, volumen de aire, volumen de agua, valor de contracción y porosidad total. [Soil improvers and growing media-Determination of physical properties - Dry bulk density, air volume, water volume, shrinkage value and total pore space].

AENOR. 2012b. UNE-EN 13037:2012. Mejoradores del suelo y sustratos de cultivo. Determinación del pH. [Soil improvers and growing media-Determination of $\mathrm{pH}$ ].

AENOR. 2012c. UNE-EN 13038:2012. Mejoradores del suelo y sustratos de cultivo. Determinación de la conductividad eléctrica. [Soil improvers and growing media - Determination of electrical conductivity].

Arán, C.L. 1977. Cultivo de pepinos por hidroponía en Lanzarote. Xoba 1:26-32. 15 July 2014. $<$ http://mdc.ulpgc.es/cdm/singleitem/collection/ xoba/id/130/rec/6>.

Arán, C.L. 1978a. Cultivo de tomate por hidroponía. Departamento de Explotación Experimental de Lanzarote. Xoba 1:143-149. 15 July 2014. $<$ http://mdc.ulpgc.es/cdm/singleitem/collection/ xoba/id/15/rec/1>

Arán, C.L. 1978b. Cultivo de melones por hidroponía. Departamento de Explotación Experimental de Lanzarote. Xoba 2:172-179. 15 July 2014. $<\mathrm{http}: / / \mathrm{mdc} . u l p g c . e s / \mathrm{cdm} /$ ref/collection/ xoba/id/24>.

Baixauli, C. and J.M. Aguilar. 2002. Cultivo sin suelo de Hortalizas. Consejería de Agricultura. Generalitat Valenciana Sèrie Divulgació Tècnica. 15 July 2014. <http://www.ivia.es/sdta/ pdf/libros/n53.pdf $>$.

Blesa, C., and A. Luque. 1972. Contribución al estudio de los materiales volcánicos de las Islas Canarias para su utilización en cultivos hidropónicos. I. Estudio de las propiedades físicas y químicas. Ann. Edaf. Agrobiol 7-8:583-599.

Burés, S. 1997. Sustrato. Agrotecnia, Madrid, Spain.

De Boodt, M., O. Verdonck, and I. Cappaert. 1974. Method for measuring the water release curve of organic substrates. Acta Hort. 37:2054-2062.

DOUE. 2000. REGLAMENTO (CE) No 790/2000 DE LA COMISIÓN de 14 de abril de 2000 por el que se establecen las normas de comercialización de los tomates. La Comisión de las Comunidades Europeas. 15 July 2014. <http:// www.boe.es/doue/2000/095/L00024-00029.pdf>.

Gericke, W.F. 1940. The complete guide to soilless gardening. Prentice Hall, Englewood Cliffs, NJ.

Gizas, G. and D. Savvas. 2007. Particle size and hydraulic properties of pumice affect growth and yield of greenhouse crops in soilless culture. HortScience 42:1274-1280.

González, E., R. Gosálvez, R. Becerra, and E. Escobar. 2008. Facies laháricas en los depósitos de oleadas piroclásticas del "Barranco Varondillo," Campo de Calatrava (Spain). Trabajos de Geomorfología en España, 2006-2008. Actas de la X Reunión Nacional de Geomorfología, Cádiz. 15 July 2014. < https://ruidera.uclm.es/xmlui/ bitstream/handle/10578/2203/fi_1332846962geomorfologia\%2020062008lahares.pdf? sequence $=1>$.

Gruda, N. and W.H. Schnitzler. 2004. Suitability of wood fiber substrates for production of vegetable transplants. II: The effect of wood fiber substrates and their volume weights on the growth of tomato transplants. Sci. Hort. 100:333-340.

Jeangille, P. 1991. Substrate for horticulture in subtropical and tropical regions. FAO, Rome, Italy.

Little, T.M. and F.J. Hill. 1978. Agricultural experimentation: Design and analysis. Wiley, New York, NY.

MAAM. 2014. Ministerio de Agricultura, Alimentación y Medio Ambiente. Inventario de sustratos de cultivo. 15 July 2014. <http:// www.magrama.gob.es/es/agricultura/temas/ medios-de-produccion/sustratos-cultivo/>. 
Martínez, A.G., G. Zárate, and M. Urrestarazu. 2012. Maguey bagasse waste as sustainable sustainable substrate in soilless culture by melon and tomato crop. J. Plant Nutr. 35:2135-2144.

McCall, W.W. and Y. Nakagawa. 1979. Growing plants without soil. Cooperative Extension Service, Circular 440. University of Hawaii, Honolulu, HI. 15 July 2014. < http://www.ctahr. hawaii.edu/oc/freepubs/pdf/C1-440.pdf>.

Morales, I. and M. Urrestarazu. 2013. Thermography study of moderate electrical conductivity and nutrient solution distribution system effects on grafted tomato soilless culture. HortScience 48:1508-1512.

Petersen, R.G. 1994. Agricultural field experiments. Marcel Dekker, New York, NY.

Ponce Lira, B., A. Ortiz Polo, E.M. Otazo Sánchez, E. Reguera Ruiz, O.A. Acevedo Sandoval, F. Prieto García, and C.C. González Ramírez. 2014. 2013. Physical characterization of an extensive volcanic rock in México: "red tezontle" from Cerro de la Cruz, in Tlahuelilpan, Hidalgo. Acta Universitaria 23:9-16.

Rodríguez, D., J. Reca, J. Martínez, R. LópezLuque, and M. Urrestarazu. 2015. Development of a new control algorithm for automatic irrigation scheduling in soilless culture. Appl. Math. Inf. Sci. 9:1-10.

Rodríguez Díaz, E., E. Salcedo Pérez, R. Rodríguez Macías, D.R. González Eguiarte, and S. Mena Munguía Salvador. 2013. Reúso del Tezontle: Efecto en sus características físicas y en la producción de tomate (Lycopersicon esculentum Mill). Terra Latinoamericana 31:275-284.

San Martín-Hernández, C., V.M. Ordaz-Chaparro, P. Sánchez-García, M.T. Beryl Colinas-León, and L. Borges-Gómez. 2012. Tomato (Solanum lycopersicum L.) quality produced in hydroponics with different particle sizes of tezontle. Agrociencia 46:243-254.

Santos, B. and D. Ríos. 2013. El picón como sustrato en cultivo sin suelo. Información Técnica. Agrocabildo. Cabildo de Tenerife. Gobierno de Canarias, Spain. 15 July 2014. <http:// www.agrocabildo.org/publica/Publicaciones/ otra_504_picon.pdf $>$.

Sonneveld, C. and N. Straver. 1994. Nutrient solutions for vegetables and flower growth in water on substrates. 10th Ed. Glasshouse Crops Research Station, Littlehampton, UK.

Urrestarazu, M. 2004. Tratado de cultivo sin suelo. Mundi-Prensa, Madrid, Spain.
Urrestarazu, M. 2013. State of art and new trends of soilless culture in Spain and in emerging countries. Acta Hort. 1013:305-312.

Urrestarazu, M., G.A. Martínez, and M.C. Salas. 2005. Almond shell waste: Possible local rockwool substitute in soilless crop culture. Sci. Hort. 103:453-460.

Urrestarazu, M., M.C. Salas, D. Valera, A. Gómez, and P.C. Mazuela. 2008a. Effects of heating nutrient solution on water and mineral uptake and early yield of two cucurbits under soilless culture. J. Plant Nutr. 31:527-538.

Urrestarazu, M., C. Guillén, P.C. Mazuela, and G. Carrasco. 2008b. Wetting agent effect on physical properties of new and reused rockwool and coconut coir waste. Sci. Hort. 116:104-108.

Urrestarazu, M., P. Mazuela, and G.A. Martínez. $2008 \mathrm{c}$. Effect of substrate reutilization on yield and properties of melon and tomato crops. J. Plant Nutr. 31:2031-2043.

Wamser, A., I. Morales, J.E. Álvaro, and M. Urrestarazu. 2014. Effect of the drip flow rate with multiple manifolds on the homogeneity of the delivered volume. J. Irrig. Drain. Eng. DOI: 10.1061/(ASCE)IR.1943-4774.0000780. 